\title{
Procedure of Building and Analysis of the Information Database of the Resistance of Existing Bridge Structures to Mining Tremors **
}

\begin{abstract}
Mining tremors are one of the manifestations of negative impacts of the mining industry on the environment. In order to protect building structures against the damaging effects of ground vibrations, it is required that their dynamic resistance be determined. This problem is of particular importance for the existing bridge structures that were not designed for the potential occurrence of mining tremors.

This paper presents the assumptions of and a method for acquiring data on the dynamic resistance of existing bridge structures located in mining areas as a result of numerical calculations using the Finite Element Method (FEM). Object resistance was described by the limit values of the acceleration of ground vibrations in the vertical and horizontal planes that can be carried by the existing structure without compromising safety. Taking into account the geometrical and material diversity, 3,000 numerical models of reinforced concrete overpasses were created. Then, for each object, numerical calculations using the FEM were performed, which resulted in the determination of permissible values of the acceleration of ground vibrations defining their dynamic resistance. The created database was subjected to a preliminary analysis in order to detect linear relationships binding the data that describe the geometry and material properties of individual structures with their dynamic resistance to the impact of mining tremors. As a result of these studies, variables were selected that formed the basis for creating a multiple linear regression model (MLR). Analysis of the obtained results allowed us to assess the possibilities of using linear models to determine the dynamic resistance of bridge structures subjected to mining tremors.
\end{abstract}

Keywords: FEM, dynamics of structures, MLR, mining tremors, dynamic resistance, bridges

* AGH University of Science and Technology, Faculty of Mining Surveying and Environmental Engineering, Krakow, Poland

** The article was prepared as part of the AGH statutory research No. 11.11.150.005 


\section{Introduction}

In the case of numerous building structures (including bridges) located in areas where seismic activity appeared only after their construction, it is necessary to assess their dynamic resistance to the impact of mining tremors. In order to determine the resistance of a given object to kinematic excitation caused by mining tremors, it is necessary to determine both its dynamic response and the criteria for determining the permissible values of ground vibration parameters that can be carried by the structure without compromising its safety [5, 11, 12, 14].

In order to determine the dynamic response of a structure, two approaches are generally used. The first one is the time analysis method (e.g., [2]). It is used especially in incidental situations when the response of a structure to a given tremor in the form of a time line of acceleration, velocity, or displacement is interesting. This approach is closest to the actual response of a structure to the kinematic excitation of supports caused by a mining tremor; e.g., [6]. However, the seismicity of a given area is not represented as a generalized time line but is rather given as a model response spectrum $[3,7,15]$. Therefore, to reflect the seismicity of a given area, this form of representing potential tremors is not widely used.

The second method, specified in the guidelines for structural design against seismic impacts, is the spectral response method [4, 7]. This approach uses curves of model response spectra (which are the frequency representations of a seismic signal for a specific area) together with information about its effect on the structure. These spectra reflect a forecast of the seismic intensity of a given area based on all seismic phenomena recorded in the past. According to [4, 8], this allows us to determine a seismic load combination already at the design stage. However, with respect to the existing structures for which there was no need to take into account a seismic combination during the design stage, it is problematic to find criteria allowing for additional impacts induced by mining tremors.

The article [14] presents a methodology for assessing the dynamic resistance of existing reinforced concrete overpasses. The criteria were given that allowed for the determination of permissible values of the acceleration of ground vibrations $a_{g}$ from mining tremors that can be carried by the structure without compromising its safety. The method described in [14] can be extended to other bridge structures as well as buildings (steel or reinforced concrete industrial portal frame buildings).

The problem of surface protection against the impacts of mining exploitation often deals with the necessity to determine the resistance of a large number of structures comprising the development in a specific mining area. In the assessment of building structures' resistance to the influences of continuous surface deformation, the Point Nuisance Method [9, 17] is used. In the case of impact assessment, on the other hand, there are empirical scales that allow us to assess the potential effects of mining tremors in buildings; e.g., [16]. 
The method of assessing the dynamic resistance proposed in [14] is dedicated to a specific object only, and the computational effort needed to carry it out is very large. Each time, it requires:

- building a numerical model with the geometrical and material properties taken into account,

- determining a load combination adopted at the design stage,

- determining a combination of seismic loads,

- determining a set of normal modes of vibration to carry out an analysis of the response spectrum,

- static FEM calculations for the defined load cases,

- numerical FEM calculations for the response spectrum method,

- recording data describing the effects of all defined load cases acting on a structure (values of internal forces, displacements, etc. for the individual structural components),

- selection of reliable cross sections for which the extreme effects of the combination of loads from the design stage have been obtained,

- comparing the extreme effects of the combination from the design stage with effects of the seismic combination,

- determining the limit values of the acceleration of ground vibrations $a_{d o p, V}$ and $a_{d o p, H}$ that equate the effects of a seismic combination with reliable effects of the combination from the design stage acting on the structure.

When analyzing a large number of objects of a given type, it is necessary to build a database on dynamic resistance for the largest range possible due to the diversity of their geometrical and material specifications. Only then will it be attainable to detect the relationships binding geometrical and material properties with the limit values of the acceleration of ground vibrations $a_{g}$. These relationships will allow us to create a model to be used as a tool for assessing the dynamic resistance of a large group of objects of a specific type without the need for numerical calculations using FEM.

This paper presents a procedure for building a database on the dynamic resistance to the impact of mining tremors on reinforced concrete overpasses with a slab span system. The selection of such a group of structures was dictated by the fact that, in mining areas, the most-common bridge structures that were not designed against the occurrence of mining tremors are overpasses with a reinforced concrete slab span system.

As a result, data on the dynamic resistance of 3,000 overpasses with different geometrical and material properties was obtained. Data mining was performed through multiple numerical FEM analyses. These analyses carried out in ABAQUS [1] were externally controlled by a specially created set of scripts and functions written in the Python programming language [13]. 
A general structure of such a database was presented, and an attempt was made to establish the relationship between geometrical and material properties and limit values of the acceleration of ground vibrations defining the resistance for each structure. An introductory analysis of these relationships and the effectiveness of applying the linear approach were conducted on a multiple regression model.

\section{Procedure of Building Database on Dynamic Resistance of Selected Group of Bridge Structures}

The analyses were carried out on a group of overpasses with a reinforced concrete slab span system. 13 subgroups were distinguished depending on the geometrical properties of these structures (Tab. 1). This division covers all of the cases in the analyzed group of structures with respect to their static schemes [10].

For each type, a set of variables was adopted describing:

- the geometry of the individual structural components,

- their material properties,

- the mechanical qualities of the bearings.

Tables 2 and 3 demonstrate a list of all variables describing a given overpass in the database. The range of their values was adopted according to [10].

The numerical calculations and results were recorded in ABAQUS using a set of scripts and control functions written in the Python programming language [13]. This allowed us to automate the process of creating the database. According to the diagram illustrated in Figure 1, the procedure for the numerical construction of the database on the dynamic resistance of the analyzed group of bridge structures each time involved:

- the random selection of the type of structure according to Table 1,

- the random selection of the geometrical and material parameters as well as the coefficient of friction for the sliding bearings according to Tables 2 and 3,

- the construction of an FEM model for the given geometrical and material parameters,

- the determination of permissible ground vibrations $\left(a_{d o p, V}\right.$ and $\left.a_{d o p, H}\right)$ according to the methodology presented in [14].

As a result of such calculations, a database on the dynamic resistance to the impact of mining tremors was obtained for 3,000 reinforced concrete overpasses with a slab span system.

Dynamic calculations used the model response spectrum for the area of the Legnica-Głogów Copper District (LGOM) as a result of adapting Eurocode 8 to the seismic conditions occurring in this area (according to [18]). 
Table 1. Summary and description of structural schemes of group of bridge structures included in study

\begin{tabular}{|c|c|c|c|c|c|}
\hline Type & $\begin{array}{l}\text { Diagram } \\
\end{array}$ & Type features & Type & Diagram & Type features \\
\hline 01 & & $\begin{array}{l}\text { - single-span } \\
\text { - free supported }\end{array}$ & 08 & & $\begin{array}{l}\text { cantilever } \\
\text { intermediate } \\
\text { supported by } \\
\text { pillars }\end{array}$ \\
\hline 02 & & $\begin{array}{l}\text { - single-span } \\
\text { - free supported } \\
\text { - with overhangs } \\
\text { - intermediate } \\
\text { supported by } \\
\text { pillars }\end{array}$ & 09 & & $\begin{array}{l}\text { cantilever } \\
\text { intermediate } \\
\text { supported by wall } \\
\text { pillars }\end{array}$ \\
\hline 03 & & $\begin{array}{l}\text { - single-span } \\
\text { - free supported } \\
\text { - with overhangs } \\
\text { - intermediate } \\
\text { supported by } \\
\text { pillars }\end{array}$ & 10 & & $\begin{array}{l}\text { multi-span } \\
\text { continuous } \\
\text { without } \\
\text { overhangs } \\
\text { intermediate } \\
\text { supported by } \\
\text { pillars }\end{array}$ \\
\hline 04 & & $\begin{array}{l}\text { - multi-span } \\
\text { - free supported } \\
\text { - without } \\
\text { overhangs } \\
\text { - intermediate } \\
\text { supported by } \\
\text { wall pillars } \\
\end{array}$ & 11 & & $\begin{array}{l}\text { multi-span } \\
\text { continuous } \\
\text { without } \\
\text { overhangs } \\
\text { intermediate } \\
\text { supported by wall } \\
\text { pillars }\end{array}$ \\
\hline 05 & & $\begin{array}{l}\text { - multi-span } \\
\text { - free supported } \\
\text { - without } \\
\text { overhangs } \\
\text { - intermediate } \\
\text { supported by } \\
\text { wall pillars }\end{array}$ & 12 & & $\begin{array}{l}\text { multi-span } \\
\text { continuous } \\
\text { with overhangs } \\
\text { intermediate } \\
\text { supported by } \\
\text { pillars }\end{array}$ \\
\hline 06 & & $\begin{array}{l}\text { - multi-span } \\
\text { - free supported } \\
\text { - with overhangs } \\
\text { - intermediate } \\
\text { supported by } \\
\text { pillars }\end{array}$ & 13 & & $\begin{array}{l}\text { multi-span } \\
\text { continuous } \\
\text { with overhangs } \\
\text { intermediate } \\
\text { supported by wall } \\
\text { pillars }\end{array}$ \\
\hline 07 & & $\begin{array}{l}\text { - multi-span } \\
\text { - free supported } \\
\text { - with overhangs } \\
\text { - intermediate } \\
\text { supported by } \\
\text { wall pillars }\end{array}$ & & & \\
\hline
\end{tabular}


Table 2. Summary of geometrical variables considered when creating database on resistance of bridge structures

\begin{tabular}{|c|c|c|c|c|}
\hline \multicolumn{5}{|c|}{ Geometrical parameters } \\
\hline $\begin{array}{l}\text { Variable } \\
\text { no. }\end{array}$ & Description of variable & \multicolumn{3}{|c|}{ Range of values } \\
\hline Var. 01 & Static scheme of system & continuous & simply supported & canilevered \\
\hline Var. 02 & Cantilevers (overhangs) & \multicolumn{2}{|l|}{ yes } & no \\
\hline Var. 03 & Number of spans & \multicolumn{3}{|c|}{$1-4$} \\
\hline Var. 04 & Length of spans & \multicolumn{3}{|c|}{ 8-36 m - depending on Variables 01 and 06} \\
\hline Var. 05 & Width of spans & \multicolumn{3}{|c|}{$6-25 \mathrm{~m}$} \\
\hline Var. 06 & Diversified height of spans & \multicolumn{2}{|l|}{ yes } & no \\
\hline Var. 07 & Height of span $H$ - support zone & \multicolumn{3}{|c|}{ Values dependent on Variables 01 and 04} \\
\hline Var. 08 & Height of span $\mathrm{h}$ - middle zone & \multicolumn{3}{|c|}{ Values dependent on Variables 01 and 04} \\
\hline Var. 09 & Length of cantilever/overhang & \multicolumn{3}{|c|}{ Values dependent on Variables 01 and 04} \\
\hline Var. 10 & $\begin{array}{l}\text { Number of support frames/wall } \\
\text { pillars }\end{array}$ & \multicolumn{3}{|c|}{ Values dependent on Variables 01,02 , and 03} \\
\hline Var. 11 & Number of pillars & \multicolumn{3}{|c|}{$\begin{array}{l}1-10 \text { values dependent on Variables } 05 \text { and } 12 \\
\text { (Value of variable equal to } 1 \text { corresponds to wall pillar) }\end{array}$} \\
\hline Var. 12 & $\begin{array}{l}\text { Width ( } y-\text { perpendicular to axis } \\
\text { of structure) of single support/ } \\
\text { wall pillar }\end{array}$ & \multicolumn{3}{|c|}{$0.6-1.6 \mathrm{~m}$} \\
\hline Var. 13 & $\begin{array}{l}\text { Width }(x-\text { parallel to axis of } \\
\text { structure) of single support/wall } \\
\text { pillar }\end{array}$ & \multicolumn{3}{|c|}{$0.6-1.6 \mathrm{~m}$} \\
\hline Var. 14 & Number of bearings & \multicolumn{3}{|c|}{ Values dependent on Variable 11} \\
\hline Var. 15 & Height of support frame lintel & \multicolumn{3}{|c|}{$0.4-1.5 \mathrm{~m}$} \\
\hline Var. 16 & Width of support frame lintel & \multicolumn{3}{|c|}{$0.3-0.6 \mathrm{~m}$} \\
\hline Var. 17 & Height of supports/wall pillars & \multicolumn{3}{|c|}{$5-10 \mathrm{~m}$} \\
\hline
\end{tabular}

Table 3. Summary of material variables considered when creating database on resistance of bridge structures

\begin{tabular}{||c|l|c||}
\hline \multicolumn{2}{|c|}{ Geometrical parameters } \\
\hline Variable no. & \multicolumn{1}{|c||}{ Description of the variable } & Range of values \\
\hline \hline Var. 18 & Modulus of elasticity of concrete in span slabs & $27-38 \mathrm{GPa}$ \\
\hline Var. 19 & Modulus of elasticity of concrete in support frame lintels & $27-38 \mathrm{GPa}$ \\
\hline Var. 20 & Modulus of elasticity of concrete in supports/wall pillars & $27-38 \mathrm{GPa}$ \\
\hline Var. 21 & Coefficient of friction of sliding bearings & $0.05-0.5$ \\
\hline
\end{tabular}




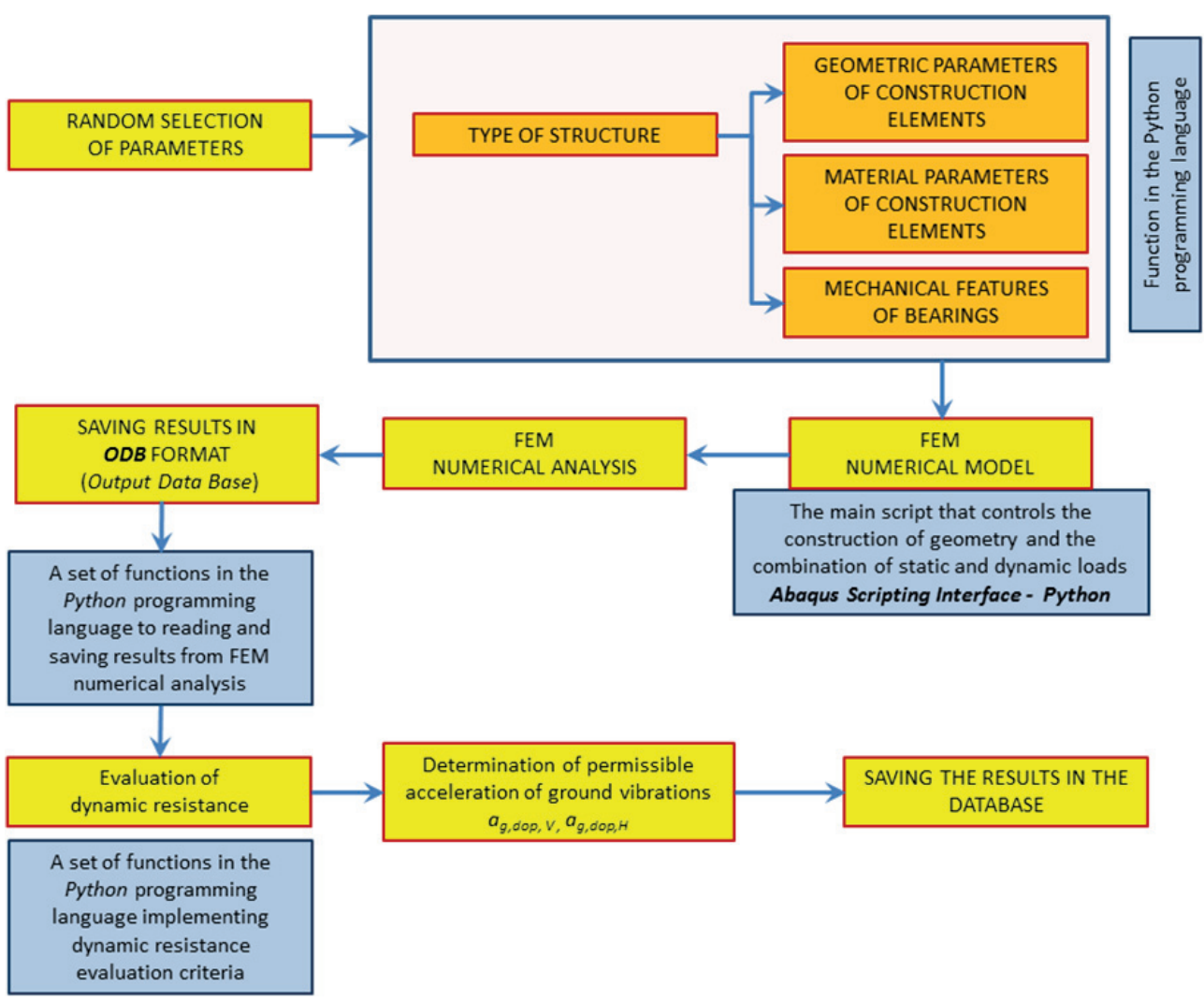

Fig. 1. Diagram of creating database on dynamic resistance for analyzed group of bridge structures

\section{Presentation of Structure and Basic Relationships in Created Database}

Having a database of 3,000 cases describing the dynamic resistance of reinforced concrete overpasses, a preliminary assessment of the relationships was made. Considering a variety of types of construction (Tab. 1) and geometrical and material properties (Tabs. 2, 3), three stages of introductory assessment of the database were carried out for the occurrence of linear dependencies.

\section{Stage I}

The first stage examined the values of the permissible acceleration of ground vibrations $\left(a_{d o p, V}\right.$ and $\left.a_{d o p, H}\right)$ that can be carried by the structure without compromising its safety for various types of construction demonstrated in Table 1. 
The obtained results in the form of mean limit values of the acceleration of ground vibrations attributed to the respective types of construction are illustrated in Figure 2 (in the horizontal plane) and Figure 3 (in the vertical plane). In the case of permissible values of $a_{g, d o p, H^{\prime}}$ this range is from $0.18 \mathrm{~m} / \mathrm{s}^{2}$ for Type 4 objects, to $0.45 \mathrm{~m} / \mathrm{s}^{2}$ for Type 2 objects. On the other hand, permissible values of the acceleration of ground vibrations in the vertical plane $\left(a_{g, d o p, V}\right)$ demonstrate that structures that are most-resistant to the dynamic impact of mining tremors are single-span simply supported ones (classified as Type 1) where the mean value of $a_{g, d o p, V}=1.87 \mathrm{~m} / \mathrm{s}^{2}$. The resistance of other types of structures is comparable, fluctuating at $0.2 \mathrm{~m} / \mathrm{s}^{2}$. Analysis of the obtained results referred to the individual types of construction did not exhibit any significant influence on the limit values of the obtained acceleration of ground vibrations.

\section{Stage II}

The second stage included an analysis aimed at detecting significant linear relationships between the variables defining the geometrical and material properties of the structural components of the objects contained in the database and the permissible values of ground vibrations $\left(a_{d o p, V}\right.$ and $\left.a_{d o p, H}\right)$ assigned to them. A preliminary analysis of correlations between the variables describing the geometrical and material properties and values obtained $\left(a_{d o p, V}\right.$ and $\left.a_{d o p, H}\right)$ was conducted. The results of these analyses (summarized in Table 4) allow for a statement that the largest linear relationship with the numerically determined values $\left(a_{d o p, V}\right.$ and $\left.a_{d o p, H}\right)$ is demonstrated by the variables describing the number of spans, cross sectional geometry of the support frame pillars, width of the support frame lintel, and height of the spans in the middle zone.

\section{Stage III}

In the third stage, an attempt was made to construct a multiple linear regression model (MLR) to estimate the permissible values of the acceleration of ground vibrations $\left(a_{d o p, V}\right.$ and $\left.a_{d o p, H}\right)$. Finally, two models were created (separate ones for horizontal and vertical components of the permissible acceleration of ground vibrations). The set of input variables for each MLR model included those variables for which significant correlations with the permissible ground vibration values $\left(a_{d o p, V}\right.$ and $\left.a_{d o p, H}\right)$ were obtained in Stage 2 (cf. Tab. 4). Table 5 summarizes the values of linear correlation coefficients between the reference values and the prediction of linear regression models (MLR) approximating the permissible values of the acceleration of ground vibrations in the vertical and horizontal planes $\left(a_{d o p, V}\right.$ and $\left.a_{d o p, H}\right)$. The obtained values for these coefficients are very low, which proves that the analyzed problem is strongly nonlinear. These results justify the adoption of methods in further studies that will allow us to build a model approximating the permissible values of ground vibrations with a large number of input variables while taking into account nonlinear effects. 


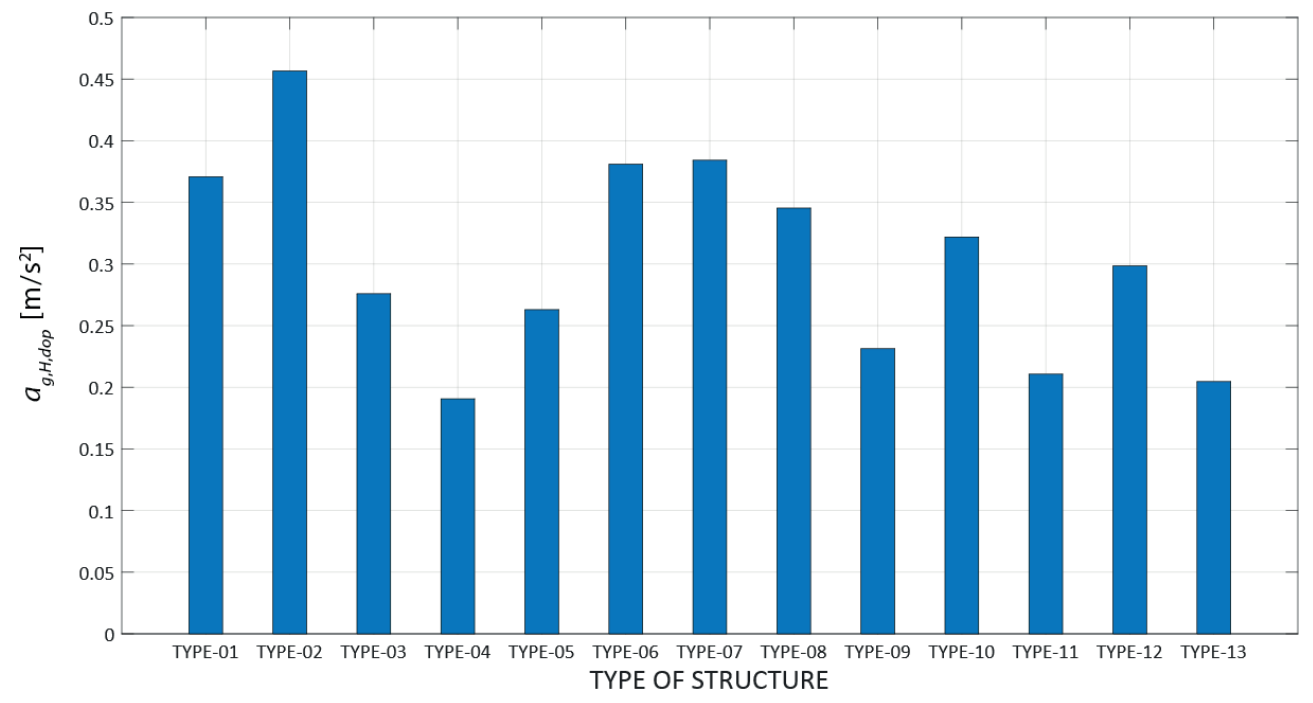

Fig. 2. Mean values of permissible acceleration of ground vibrations $a_{g, H, d o p}$ obtained for individual types of supporting structures of analyzed group of objects cf. Table 1

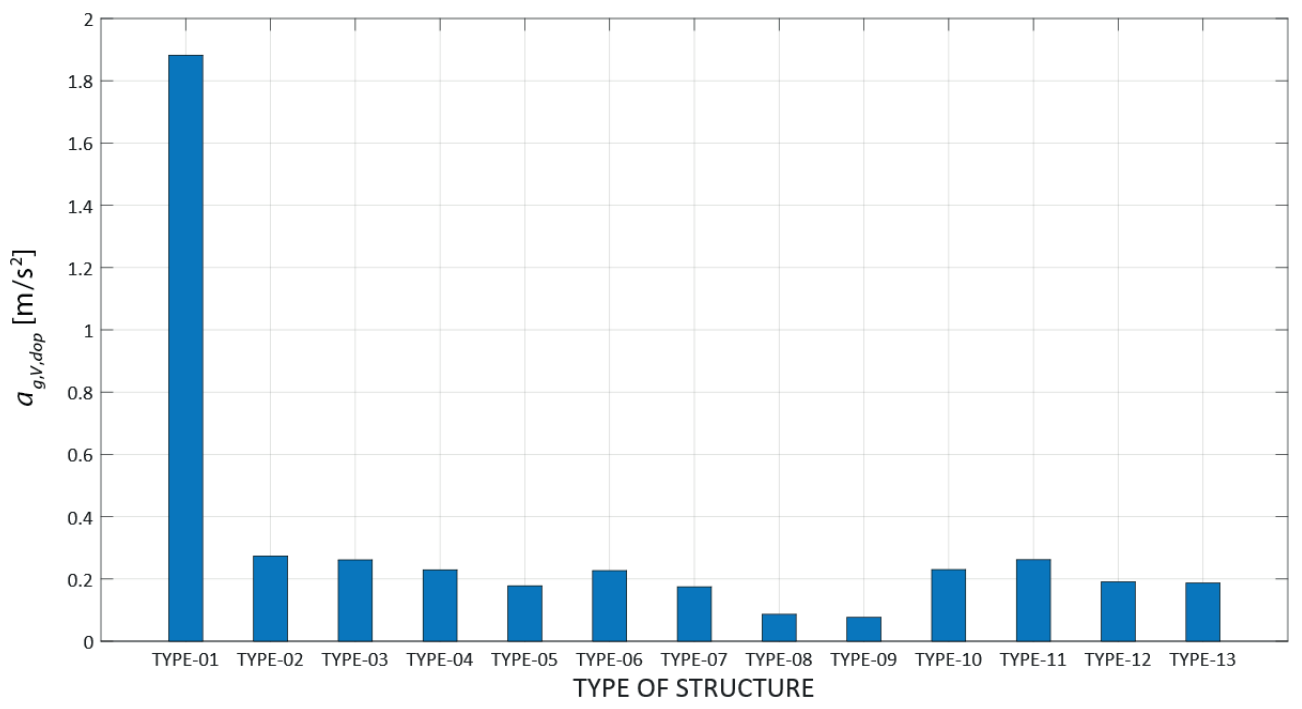

Fig. 3. Mean values of permissible acceleration of ground vibrations $a_{g, V, \text { dop }}$ obtained for individual types of supporting structures of analyzed group of objects cf. Table 1 
Table 4. Values of coefficients of linear correlation between variables describing geometrical and material properties as well as permissible values

of acceleration of ground vibrations

\begin{tabular}{|c|c|c|c|}
\hline $\begin{array}{l}\text { Variable } \\
\text { no. }\end{array}$ & Description of variable & $\begin{array}{l}\text { Value of linear } \\
\text { correlation coefficient } \\
\text { relative to } a_{g, H, \text { dop }}\end{array}$ & $\begin{array}{l}\text { Value of linear } \\
\text { correlation coefficient } \\
\text { relative to } a_{g, V, d o p}\end{array}$ \\
\hline Var. 03 & Number of spans & -0.182 & -0.403 \\
\hline Var. 04 & Length of span & 0.083 & -0.086 \\
\hline Var. 05 & Width of span & 0.049 & -0.056 \\
\hline Var. 07 & Height of span in support zone & 0.105 & -0.087 \\
\hline Var. 08 & Height of span in middle zone & 0.056 & -0.048 \\
\hline Var. 09 & Length of overhang & -0.016 & -0.005 \\
\hline Var. 11 & Number of pillars in support frame & 0.086 & 0.089 \\
\hline Var. 12 & $\begin{array}{l}\text { Width of pillar in support frame/wall } \\
\text { pillar in direction } y \text { - perpendicular to } \\
\text { axis of structure }\end{array}$ & -0.141 & -0.079 \\
\hline Var. 13 & $\begin{array}{l}\text { Width of pillar in support frame/wall } \\
\text { pillar in direction } x \text { - parallel to axis } \\
\text { of structure }\end{array}$ & -0.050 & -0.268 \\
\hline Var. 14 & Number of bearings in support zone & 0.012 & -0.083 \\
\hline Var. 15 & Height of support frame lintel & -0.002 & -0.033 \\
\hline Var. 16 & Width of support frame lintel & -0.052 & -0.275 \\
\hline Var. 17 & Height of supports/wall pillars & -0.006 & 0.080 \\
\hline Var. 18 & $\begin{array}{l}\text { Modulus of elasticity of concrete of } \\
\text { spans }\end{array}$ & -0.047 & -0.069 \\
\hline Var. 19 & $\begin{array}{l}\text { Modulus of elasticity of concrete of } \\
\text { support frame lintels }\end{array}$ & 0.037 & -0.008 \\
\hline Var. 20 & $\begin{array}{l}\text { Modulus of elasticity of concrete of } \\
\text { supports/wall pillars }\end{array}$ & 0.003 & -0.009 \\
\hline Var. 21 & $\begin{array}{l}\text { Coefficient of friction of sliding } \\
\text { bearings }\end{array}$ & -0.086 & -0.055 \\
\hline
\end{tabular}

Results obtained at significance level $p<0.05$ marked in red.

Table 5. Values of coefficients of linear correlation between real values and prediction of linear models for estimation of permissible acceleration of ground vibrations $a_{g, V, d o p}$ and $a_{g, H, d o p}$

\begin{tabular}{|c|c|}
\hline $\begin{array}{c}\text { Value of coefficient of linear combination } \\
\text { between real values and prediction of model } \\
\text { approximating value of } a_{g, H, d o p}\end{array}$ & $\begin{array}{c}\text { Value of coefficient of linear combination } \\
\text { between real values and prediction of model } \\
\text { approximating value of } a_{g, V, d o p}\end{array}$ \\
\hline 0.29 & 0.45 \\
\hline
\end{tabular}




\section{Summary and Conclusions}

The procedure described in this paper can be applied to other types of bridge structures and to portal frame buildings as well. Such a large set of data on the resistance of structures of a given type may allow us to build an approximating model, replacing a very complex FEM analysis. The ability to quickly assess the resistance of a specific structure or group of structures may allow for an effective variant analysis, which is necessary in those cases where information on the material properties is uncertain. These variants results from the dispersion of the measured values of strength and frequently requires multiple calculations.

A linear regression model was assessed in this paper. Assessment of the efficiency of this model demonstrates that further research should be carried out in order to search for a method that would allow to include the phenomenon of nonlinearity in the model.

\section{References}

[1] ABAQUS: ABAQUS Documentation. Dassault Systemes. Providence, USA 2011.

[2] Betti M., Galano L., Vignoli L.A.: Time-History Seismic Analysis of Masonry Buildings: A Comparison between Two Non-Linear Modelling Approaches. Buildings, vol. 5(2), 2015, pp. 597-621.

[3] Chmielewski T., Zembaty Z.: Podstawy dynamiki budowli [The rudiments of the dynamics of structures]. Arkady, Warszawa 2006.

[4] Cholewicki A., Kawulok M., Lipski Z., Szulc J.: Zasady ustalania obciażeń $i$ sprawdzania stanów granicznych budynków zlokalizowanych na terenach górniczych w nawiazaniu do Eurokodów [Rules for determining the load and checking limit states of buildings located on mining areas in reference to the Eurocodes]. Instytut Techniki Budowlanej, Warszawa 2012.

[5] Ciurej H., Rusek J.: Metodyka oceny odporności dynamicznej wybranych obiektów mostowych na terenie LGOM [Methodology of assessment dynamic resistance of selected bridges in LGOM]. Czasopismo Techniczne. Budownictwo, R. 103, z. 13-B, 2006, pp. 31-57.

[6] Dulińska J., Zięba A.: Metody oceny wpływu wstrzasów górniczych na wybrane budowle wielkogabarytowe [Methods of assessing the impact of mining tremors on selected large-size structures]. Czasopismo Techniczne. Budownictwo, R. 107, z. 3-B, 2010, pp. 31-42.

[7] Eurocode, C.E.N. European Committee for Standardization. Design of Structures for Earthquake Resistance 1998.

[8] Eurocode, C.E.N. European Committee for Standardization. Basis of structural design 1990. 
[9] Kwiatek J.: Obiekty budowlane na terenach górniczych [Buildings in mining areas]. Wyd. 2 zm. i rozsz. Główny Instytut Górnictwa, Katowice 2007.

[10] Madaj A., Wołowicki W.: Projektowanie mostów betonowych [Design of concrete bridges]. Wydawnictwa Komunikacji i Łączności, Warszawa 2010.

[11] Majcherczyk T., Tatara T., Wałach D.: Wpływ drgań powierzchniowych wywołanych wstrzasami górniczymi na konstrukcje wież szybowych [The influence of surface vibrations caused by mining tremors on structures towers shaft]. WUG: Bezpieczeństwo Pracy i Ochrona Środowiska w Górnictwie, nr 6, 2005, pp. 21-23.

[12] Pachla F., Tatara T.: Odporność dynamiczna obiektów infrastruktury drogowej i sportowej na wybranym obszarze GZW [Resistance dynamic road infrastructure and sports on a selected area of Upper Silesian Coal Basin]. Przegląd Górniczy, t. 71, nr 10, 2015, pp. 42-50.

[13] Python Software Foundation. Python Language Reference, version 2.7, [on-line:] http://www.python.org., 2016 [access: 18.09.2017].

[14] Rusek J.: Proposal evaluation of dynamic resistance of the existing reinforced concrete slab viaduct to the impact of mining tremors. Czasopismo Inżynierii Lądowej, Środowiska i Architektury, t. 34, z., 2017, pp. 469-485.

[15] Tatara T.: Odporność dynamiczna obiektów budowlanych w warunkach wstrzasów górniczych [Dynamic resistance of buildings in terms of mining tremors]. Wyd. Politechniki Krakowskiej im. Tadeusza Kościuszki, Kraków 2012.

[16] Tatara T.: Proponowane kierunki dalszej modyfikacji skali GSI-GZW/KW [Proposed directions for further modification of the GSI-GZW/KW scale]. Przegląd Górniczy, t. 69, nr 11, 2013, pp. 17-24.

[17] Wodyński A.: Zużycie techniczne budynków na terenach górniczych [Technical wear of buildings in mining areas]. Uczelniane Wydawnictwa Naukowo-Dydaktyczne AGH, Kraków 2007.

[18] Zembaty Z., Kokot S.: Adaptacja sejsmicznych norm projektowania konstrukcji do ujęcia wptywu wstrząsów górniczych na budowle [Adaptation of seismic design standards structure to include the impact of mining tremors on buildings]. Przegląd Górniczy, t. 70, nr 6, 2014, pp. 72-77.

\section{Procedura budowy i analiza bazy informacji o odporności istniejących obiektów mostowych na wstrząsy górnicze}

Streszczenie: Jednym z przejawów negatywnego wpływu działalności przemysłowej kopalń na środowisko są wstrząsy górnicze. Ochrona obiektów budowlanych przed szkodliwym działaniem wynikających stąd drgań podłoża gruntowego wymaga ustalenia ich odporności dynamicznej. Problem ten nabiera 
szczególnego znaczenia w przypadku istniejących obiektów mostowych, przy których projektowaniu nie uwzględniono możliwości wystąpienia wstrząsów górniczych.

W pracy przedstawiono metodę pozyskiwana danych o odporności dynamicznej istniejących obiektów mostowych usytuowanych na terenach górniczy w wyniku obliczeń numerycznych metodą elementów skończonych (MES). Odporność obiektów opisano za pomocą granicznych wartości przyspieszeń drgań gruntu w płaszczyźnie pionowej i poziomej, które istniejąca konstrukcja może przejąć bez zagrożenia bezpieczeństwa. Uwzględniając zróżnicowanie geometryczne i materiałowe, utworzono 3000 modeli numerycznych żelbetowych mostów drogowych. Następnie w odniesieniu do każdego obiektu przeprowadzono obliczenia numeryczne MES, w wyniku których dla każdego przypadku wyznaczono dopuszczalne wartości przyspieszeń drgań gruntu określających ich odporność dynamiczną. Utworzoną bazę danych poddano wstępnej analizie w celu wykrycia linowych relacji wiążących dane opisujące geometrię i właściwości materiałowe poszczególnych obiektów z ich odpornością dynamiczną na wpływ wstrząsów górniczych. W efekcie tych badań wyselekcjonowano zmienne, na podstawie których utworzono model wielorakiej regresji liniowej (MLR). Analiza uzyskanych wyników pozwoliła ocenić możliwości stosowania modeli liniowych do ustalania odporności dynamicznej obiektów mostowych poddanych wstrząsom górniczym.

Słowa

kluczowe: MES, dynamika budowli, MLR, wstrząsy górnicze, odporność dynamiczna, mosty 
